\title{
A comparison of frontal, continuous, and rota- tion grazing systems
}

\author{
J.D. VOLESKY, F. DE ACHAVAL O’FARRELL, W.C. ELLIS, M.M. KOTHMANN, F.P. \\ HORN, W.A. PHILLIPS, AND S.W. COLEMAN
}

Volesky, Phillips, and Coleman are research scientists with the USDA-ARS Grazinglands Research Lab., P.O. Box 1199, El Reno, Okla. 73036. Achaval is a former graduate research assistant. Tucuman 410 Piso 1, Buenos Aires, (1049), Argentina. Horn is area director, USDA-ARS Southern Plains Area, College Station, Tex. 77843. Ellis is a professor in the Department of Animal Science and Kothmann is a professor in the Department of Rangeland Ecology and Management at Texas A\&M University, College Station 77843.

\section{Abstract}

Two 2-year trials were conducted to evaluate and compare frontal, continuous, and 2-paddock rotation grazing systems on 'Plains' Old World bluestem (Bothriochloa ischaemum (L.) Keng.). Frontal grazing allows livestock a continuous opportunity to graze fresh forage via a livestock-pushed, sliding fence which allocates and controls grazing within a pasture. Trial 1 treatments included frontal grazing at a very high stocking density of 13.3 head ha-1 and continuous grazing at 4 stocking densities described as low, moderate, high, and very high. The mechanical design and components of our frontal grazing system were quite adequate in terms of the system's operation and interaction with the livestock herd. Significant $(P<0.05)$ linear relationships were found for regressions of daily gain on stocking rate and grazing pressure index, and for gain $\mathrm{ha}^{-1}$ on stocking rate and grazing pressure index. Year effects were evident in all regressions. Trial 2 treatments included frontal, continuous, and rotation grazing systems initially stocked at 6.7 head $\mathrm{ha}^{-1}$. Mid-season reductions in stocking density were made in continuous and rotation grazing to ensure that these treatments would have adequate forage to continue until frontal grazing completed its second cycle and to achieve an end-of-season standing crop which was similar in all 3 treatments. Season-long daily gains under frontal grazing were not significantly different compared to continuous grazing $(P>0.05)$; however, they were less than those under rotation grazing $(P<0.05)$. Frontal grazing provided about 100 more steer-days per hectare of grazing than either continuous or rotation grazing. However, steer production was not significantly different among treatments and averaged $296 \mathrm{~kg} \mathrm{ha}^{-1}$ $(P>0.05)$.

Key Words: Bothriochloa ischaemum, 'Plains' Old World Bluestem, steer performance, steer production, stocking rate

Grazing systems and associated management practices can substantially influence grazing patterns and utilization of a pasture. Patterns of selection and defoliation are probably the most important effects of the grazing animal on the pasture. Not only is a leaf area reduced, with concomitant effects on carbohydrate storage, tiller development, and leaf and root growth, but also the microenvironment (e.g., light intensity, soil temperature and moisture) is altered, which in turn affects plant growth (Watkin and Clements (1978). Although evidence indicates that important gains in herbage yield can be obtained from defoliation management, it remains a matter of controversy whether such management results in significant gains in animal production (Morley 1968).

Manuscript accepted 13 Nov. 1993.
Frontal grazing is a method of intensive grazing management which allows livestock a continuous opportunity to graze fresh forage (Volesky 1990). According to Pereda (personal communication ${ }^{1}$, frontal grazing relies heavily upon animal behavior. The system features a livestock-driven sliding fence that allocates and controls grazing within a pasture. Cattle advance the moveable fence by collectively pushing a cable with their foreheads to gain access to ungrazed forage. This system utilizes high stocking densities but has the potential advantage of having a minimal amount of forage lost due to trampling or fouling by excreta (Volesky et al. 1990). The system has some similarities with short-duration or rotational grazing systems that have short residence periods in a subunit (paddock) and relatively high stocking densities. Even more of an association can be drawn with a grazing management system reported by McMeekan (1947). His system required the allocation of a fresh strip of forage 2 or 3 times a day.

This research had multiple objectives. Of primary interest was the development of a knowledge base pertaining to the requirements, operation, and management of a frontal grazing system. In addition, comparisons of livestock performance and production were made between frontal and more conventional systems.

\section{Materials and Methods}

These studies were conducted from 1989 through 1992 at the USDA-ARS Grazinglands Research Laboratory near El Reno, Okla. The $807 \mathrm{~mm}$ long-term mean annual precipiptation at this location is bimodally distributed with peaks during May and September. Study pastures were dominated by 'Plains' Old World bluestem (Bothriochloa ischaemum L.). Soils were fine-silty Udic Paleustolls of the Norge series. All pastures were burned in March and received $84 \mathrm{~kg} \mathrm{ha}^{-1} \mathrm{~N}$ in late April of each year.

\section{Trial 1}

Trial 1 was conducted during 1989 and 1990 . Treatments were replicated twice and included frontal grazing stocked at 13.3 head $\mathrm{ha}^{-1}$ and continuous grazing at 4 different stocking densities. The main feature of the frontal grazing system was a $100-\mathrm{m}$ wide livestock-pushed frontal fence. Components of the frontal fence included: (1) an electric wire and an insulated push-cable; (2) a centrally located pace-governor; and (3) sleds which supported the

(Personal communication). The main components and equipment for frontal grazing are patented and manufactured by Fernando R. Pereda, Tucuman 410, Piso 1. (1049) Buenos Aires, Argentina. The authors thank Bobby D. Handke, USDA-ARS technician, for assistance in livestock management and Fernando $R$. Pereda for providing the frontal grazing equipment.

Mention of trade names, proprietary products, or specific equipment does not constitute a guarantee or warranty of the product by the USDA and does not imply its approval to the exclusion of other products that may also be suitable. 
electric wire and push-cable. The frontal fence was attached at each end to a single high-tensile lateral wire through a bracketed set of pulleys. Additional fencing included an alley in which livestock traveled to water and a movable back-fence. Operation and components of the frontal grazing system are further described by Volesky (1990), Volesky et al. (1990), and Achaval O'Farrell (1991).

Frontal grazing pastures were $100-\mathrm{m}$ wide and $750-\mathrm{m}$ long (7.5 ha). The frontal fence was initially placed at one end about $50 \mathrm{~m}$ from a permanent back-fence. This initial 0.5 -ha area was stocked with 100 steers. Steers were adapted to frontal grazing and able to effectively push the frontal fence after a 7- to 10-day training period. Training the steers to frontal grazing consisted of periodically manually pulling the frontal fence ahead about $0.5 \mathrm{~m}$ to expose a strip of ungrazed forage. Steers would readily approach the frontal fence to graze this forage. As the steers advanced the frontal fence across the pasture, a back-fence was periodically moved to maintain it at a distance of 60 to $120 \mathrm{~m}$ from the frontal fence. This prevented steers from accessing the area that had been already grazed. Stocking density in frontal grazing was 13.3 head $\mathrm{ha}^{-1}$ based on the entire frontal grazing pasture. However, a realtime stocking density, based on the distance between the frontal fence and back-fence ranged from 83 to 167 head ha $^{-1}$ depending on the position of the frontal or back-fence.

Size of the continuous grazing pastures was 0.9 ha. Initial stocking densities in 1989 were $4.4,6.7,8.9$, and 11.1 head $^{-1}$ for the low, moderate, high, and very high densities, respectively. Stocking densities were increased an average of $25 \%$ in 1990 to overlap that of frontal grazing.

Frontal grazing was started on 14 June 1989 and the first cycle (passage over the $750-\mathrm{m}$ pasture length) lasted 30 days. Cattle were removed from the pastures for a 16-day intermediate regrowth period and a second frontal grazing cycle was started on 1 August and lasted for 18 days. Cattle grazed a nearby 'Plains' bluestem pasture during the intermediate period. Rate of frontal fence advancement was related to quantity and quality of available forage and averaged 25 and $42 \mathrm{~m} \mathrm{day}^{-1}$ for cycles 1 and 2, respectively. Continuous grazing started on 14 June and ended 18 August with an extended grazing period until 30 August with an extended grazing period until 30 August for the light and moderate treatments. Grazing began on 24 May in 1990 and frontal grazing cycle 1 lasted until 24 June. Cycle 2 began immediately and lasted until 5 July. Rates of frontal fence advancement were 24 and $75 \mathrm{~m} \mathrm{day}^{-1}$ for cycles 1 and 2, respectively. Continuous grazing began on 24 May and lasted until 13 July for heavy and very heavy treatments and until 7 August for the light and moderate treatments.

Forage standing crop was estimated on a weekly basis in both frontal and continuous grazing pastures using an electronic capacitance meter (Vickery et al. 1980). One-hundred readings were taken at random throughout each continuous grazing pasture. Readings in frontal grazing were taken along transects immediately before grazing and then during the same day, after steers had advanced the frontal fence over the transects. Differences in these before and after standing crop estimates were used to determine forage utilization. The capacitance meter was calibrated with clipped samples taken over the summer grazing period. Our prediction equation was as follows: $\mathrm{kg} \mathrm{ha}^{-1}=-167.95+13.647 *$ meter reading $\left(P<0.01, R^{2}=0.84, \mathrm{~N}=230\right)$.

\section{Trial 2}

Trial 2 was conducted during 1991 and 1992. Treatments were replicated twice and included frontal, continuous, and a 2-paddock rotation grazing system. It was apparent from trial 1 that our pasture area for frontal grazing was too small to support 100 steers for more than 40 to 50 days. Existing $100-\mathrm{m}$ wide frontal grazing pastures were divided in half creating 2 adjacent strips each $50-\mathrm{m}$ wide and 750-m long. Fifty steers were used in this modified system. Two cycles under frontal grazing were completed with the first lasting 60 days both years resulting in an average frontal fence movement of $25-\mathrm{m} \mathrm{day}{ }^{-1}$. The second cycle lasted an average of 20 days $\left(75-\mathrm{m} \mathrm{day}^{-1}\right)$. Twenty-five percent of each frontal grazing pasture, covering the area that would be grazed last, was cut for hay in mid-June because forage would be excessively mature by the time it was frontally grazed. Hay yield from this area averaged about $3,000 \mathrm{~kg} \mathrm{ha}^{-1}$ each year.

Initial stocking density for trial 2 in all treatments was 6.7 head $\mathrm{ha}^{-1}$. Put-and-take steers were used to ensure that all treatments had a similar amount of residue $\left(1,500 \mathrm{~kg} \mathrm{ha}^{-1}\right)$ left at the end of the summer. Decision-making pertaining to stocking adjustments was assisted by standing crop measurements and rainfall patterns. Pastures for continuous and rotation grazing treatments were 1.8 ha in size with rotation pastures subdivided into 2 equal paddocks. Steers were rotated between paddocks every 2 to 3 weeks.

Crossbred steers with a mean initial live weight of $265 \mathrm{~kg}$ were used for both trials 1 and 2. Cattle were penned for an overnight shrink and weighed about every 30 days or at the completion of a frontal grazing cycle.

Forage standing crop was estimated at 2- to 3-week intervals in all treatments using the same methods described for trial 1. End-ofseason standing crop was determined by clipping 10 randomly placed $0.25 \mathrm{~m}^{2}$ quadrats in each continuous and rotation grazing pasture. Ten quadrats were clipped in each of 4 equal sectors of a frontal grazing pasture. Each sector included $25 \%$ of the area in the pasture with sector 1 being grazed first during a cycle and sector 4 being grazed last. Clipped samples were hand-sorted into grasses and forbs, oven-dried, and respective components weighed.

\section{Statistical Methods}

Trial 1 data were subjected to regression analyses using general linear models (GLM) procedures (SAS Institute Inc. 1988). Linear and quadratic relationships were examined with daily gain and gain per hectare regressed against animal unit days per hectare (AUD ha ${ }^{-1}$ ) and grazing pressure index. Animal unit days were calculated based on a grazing pressure equivalent to $454 \mathrm{~kg}$ of live weight. The short-term net effect of different grazing systems on animal productivity was evaluated so that relative responses at a common grazing pressure index could be evaluated. Because only 1 frontal grazing pressure was used, response of this grazing pressure was compared to the generalized response in productivity per animal and per land area on continuous grazing treatments. Grazing pressure index was calculated as follows:

$$
\text { Grazing pressure index }=\frac{\text { AUD *12 }}{\text { MSC }}
$$

where MSC is mean standing crop and $12 \mathrm{~kg}$ is the forage demand for 1 AUD.

Trial 2 daily gain and gain per hectare data were analyzed using analysis of variance. Main effects were year, treatment, and replication. The error mean square for detecting treatment effects was treatment by replication. The residual error mean square was used to test for year and year by treatment effects. A similar model was used for end-of-season standing crop data which also included data from the 4 sectors of frontal grazing.

\section{Results and Discussion}

\section{Trial 1}

\section{Frontal Grazing System}

It is important to note that overall mechanical design and construction of the frontal grazing system was adequate. Operation of the system by the steers promoted uniform and efficient forage use. Grazing in 1989 began 14 June when standing crop in frontal 
grazing pastures averaged $3,070 \mathrm{~kg} \mathrm{ha}^{-1}$. Grazing began 24 May in 1990 when standing crop averaged $2,110 \mathrm{~kg} \mathrm{ha}^{-1}$. Forage utilization that occurred during advancement of the frontal fence was 48 and $66 \%$ in 1989 and 1990 , respectively. The difference in utilization between years was presumably associated with starting date and growth stage of the 'Plains' bluestem forage. The bluestem in 1989 had already begun to produce seed heads, thereby encouraging a level of selective grazing that tended to reduce utilization. The period of greatest forage utilization occurred as the steers initially grazed the forage made available by advancing the frontal fence. Measurements on the same area 3 to 4 days later and immediately before the area was excluded from grazing by the back-fence, showed an additional forage disappearance of 15 to $20 \%$.

Steer behavior under the frontal grazing system was observed to be herd-oriented. Generally, grazing events began with 1 or 2 steers walking up to the frontal fence to begin grazing and these were quickly joined by the remaining steers. Steers followed a similar pattern when exiting the frontal grazing pasture into the alley for water. A hierarchy developed with respect to where steers grazed along the frontal fence. Specific steers consistently chose to graze at the frontal fence supporting sleds where it is easiest to push and advance the frontal fence. These steers were usually those that expressed the least fear in approaching and pushing the frontal fence during the initial training period.

\section{Animal Production}

There was a significant year by stocking rate interaction for the regression of daily gain on $A_{U D}$ ha $^{-1}(P<0.05$; Fig. 1). This indi-

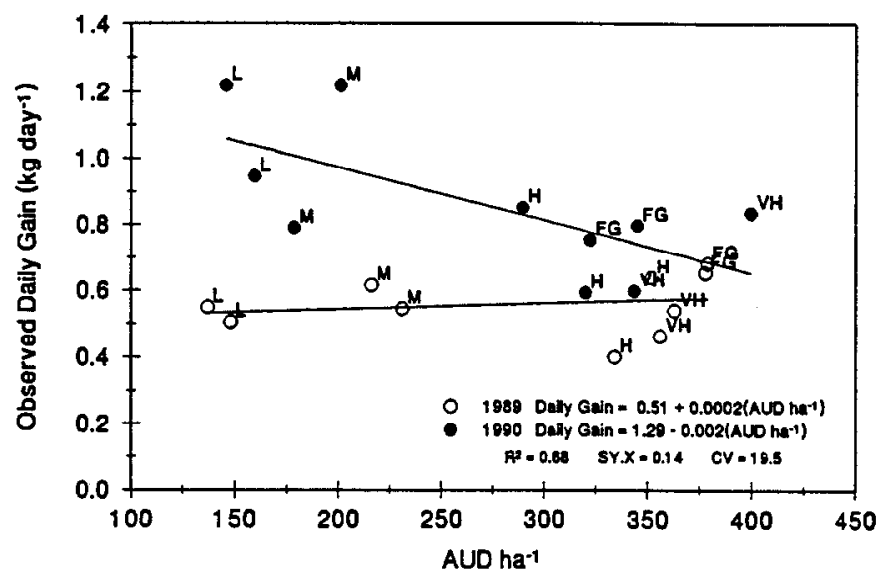

Fig. 1. Relationship between daily gains and stocking rates (AUD ha-1) during 1989 and $1990 . \mathrm{L}, \mathrm{M}, \mathrm{H}$, and VH refer to light, moderate, heavy, and very heavy continuous grazing treatments and FG refers to frontal grazing.

cates that slopes were different with respect to years. The slope was nearly zero in 1989, whereas in 1990 there was an inverse relationship between AUD ha ${ }^{-1}$ and daily gain. The linear relationship observed with the 1990 data is consistent with that reported by Mott (1960) and Hart (1980).

Year had a significant effect in the regression of gain ha ${ }^{-1}$ on AUD ha ${ }^{-1}(P<0.01$; Fig. 2). Gains were less in 1989 compared to 1990, which we hypothesize were at least partially due to reduced forage quality on offer resulting from the 3 week later start of grazing in 1989. Dabo et al. (1988) reported that 'Plains' bluestem has a rapid decline in crude protein content of leaves and particularly stems with maturation. The relationship of gain ha ${ }^{-1}$ and AUD ha ${ }^{-1}$ reflects effects of animal-forage interactions involving harvesting efficiency per hectare. Both gain ha ${ }^{-1}$ and AUD ha were similar for frontal, heavy, and very heavy treatments.

There was a significant year by grazing pressure index interac-

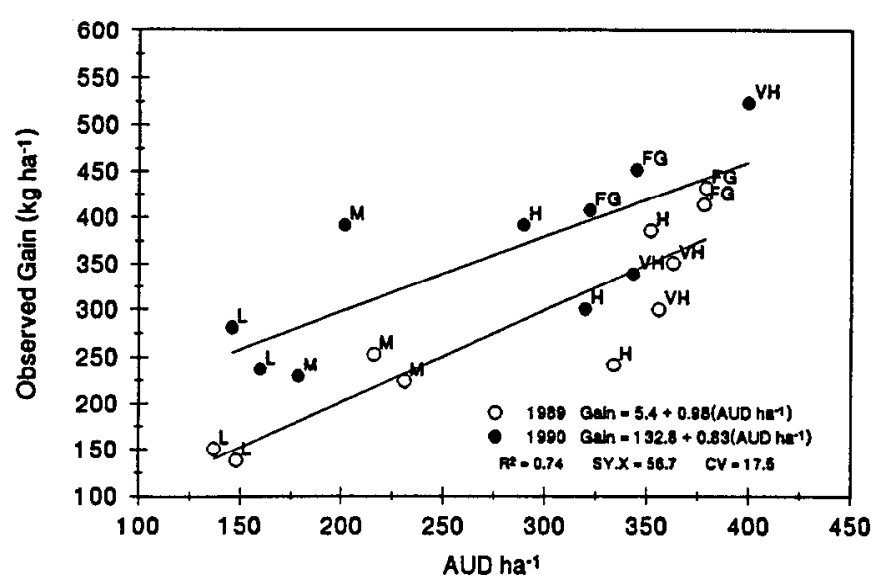

Fig. 2. Relationship between gains (kg ha $\left.{ }^{-1}\right)$ and stocking rates (AUD $\mathrm{ha}^{-1}$ ) during 1989 and 1990 . L, M, H, and VH refer to light, moderate, heavy, and very heavy continuous grazing treatments and FG refers to frontal grazing.

tion for the regression of daily gain on grazing pressure index indicating that slopes were different due to years ( $P<0.05$; Fig. 3). This relationship was similar to that of daily gain on AUD ha (Fig. 1). The slope for the 1989 data was nearly zero but in 1990 , daily gain declined with an increase in grazing pressure index. The

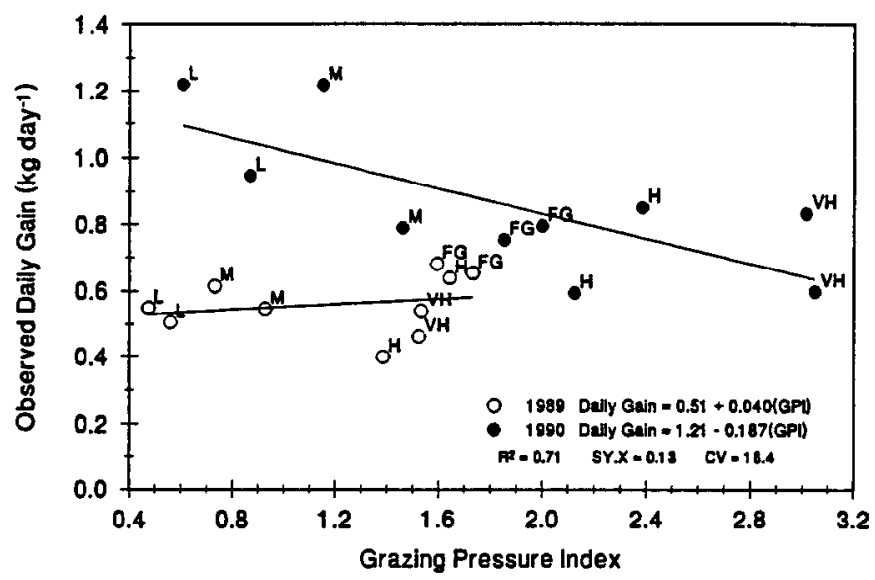

Fig. 3. Relationship between daily gains and grazing pressure indices (GPI) during 1989 and 1990 . L, M, H, and VH refer to light, moderate, heavy, and very heavy continuous grazing treatments and FG refers to frontal grazing.

range of grazing pressure index in 1989 was relatively small due in part to the high mean standing crop and short grazing period. There was a positive linear relationship between gain per hectare and grazing pressure index both years (Fig. 4). The year by grazing pressure index interaction was significant $(P<0.05)$ again indicating that slopes were different due to years.

None of our models were significantly improved by using a higher order polynomial $(P>0.05)$. The response of gain $\mathrm{ha}^{-1}$ to stocking rate or grazing pressure index would typically be expected to have a quadratic relationship (Hart et al. 1980, Conway 1963). Our data were limited because of the fairly close range of stocking rates which in part, arose from having only 48-and 42-day grazing periods in 1989 and 1990 , respectively.

\section{Trial 2}

\section{Frontal Grazing System}

The more moderate stocking of 6.7 head ha $\mathrm{ha}^{-1}$ allowed frontal grazing periods of use of 76 and 86 days in 1991 and 1992, respec- 


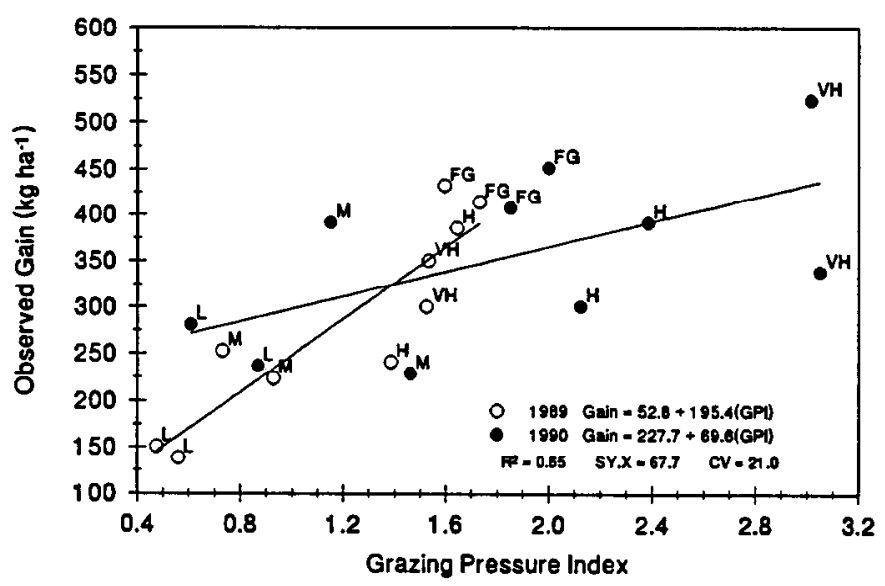

Fig. 4. Relationship between gains $\left(\mathrm{kg} \mathrm{ha}^{-1}\right)$ and grazing pressure indices (GPI) during 1989 and 1990 . L, M, H, and VH refer to light, moderate, heavy, and very heavy continuous graxing treatments and FG refers to frontal grazing.

tively. Cycle 1 lasted 60 days both years with a rate of frontal fence advancement of $25 \mathrm{~m} \mathrm{day}^{-1}$. This length of use appeared near optimum as it provided the frontal grazing starting area with a nearly 60-day regrowth period. However, rate of frontal fence advancement for cycle 2 was much faster $\left(70 \mathrm{~m} \mathrm{day}^{-1}\right)$, which progressively decreased the regrowth periods to about $\mathbf{4 0}$ days for frontal grazing sector 2, 30 days for sector 3, and 20 days for sector 4.

Cutting hay from frontal grazing sector 4 during mid-June also appeared to be advantageous. This area would not normally have been frontally grazed until day $\mathbf{4 5}$ of frontal grazing (mid-July) and the 'Plains' bluestem would be relatively mature with reduced palatability and quality compared to the regrowth after haying.

\section{Steer Production and Forage Utilization}

There were no significant year or year by treatment interactions for daily gain or gain per hectare $(P>0.05)$. Season-long daily gain under frontal and continuous grazing was not significantly different $(P>0.05)$; however, season-long daily gain under rotation grazing was significantly greater compared to frontal grazing (Table 1). Early summer daily gain, which included the first 30 days of grazing, was less under frontal compared to continuous or rotation grazing $(P<0.05)$. It was hypothesized that forage intake of frontal grazing steers during the initial 7- to 10-day training and adaptation period was moderately depressed. This was indirectly quantified by comparing the slow rates of frontal fence advancement during the initial 10 days to faster rates during subsequent periods. Late summer daily gain which included the frontal grazing cycle 2 period was significantly greater until frontal and rotation compared to continuous grazing ( $P<0.05$ ). Achaval O'Farrel (1991) reported crude protein of available forage from frontal grazing cycle 2 to be greater than that under continuous grazing on similar dates.
Frontal grazing provided about 100 more steer-days ha $^{-1}$ of grazing than continuous and rotation grazing (Table 1). However, steer production was not significantly different among treatments and averaged $296 \mathrm{~kg} \mathrm{ha}^{-1}(P>0.05)$. The increased steer-days ha $\mathrm{h}^{-1}$ under frontal grazing did not reflect higher gain ha $\mathrm{ha}^{-1}$ because of lower daily gain.

Total end-of-season herbage standing crop averaged $1,430 \mathrm{~kg}$ $\mathrm{ha}^{-1}$ and was not different among treatments $(P>0.05$, Table 2$)$.

Table 2. End-of-season herbage standing crop $\left(\mathrm{kg} \mathrm{ha}^{-1}\right)$ averaged over 1991 and 1992.1

\begin{tabular}{lccc}
\hline \hline Treatment & Grass & Forb & Total \\
\hline & $\cdots \ldots$ & $(\mathrm{kg} / \mathrm{ha})$ & $\ldots \ldots \ldots$ \\
Frontal grazing & $\ldots \ldots 0^{\mathrm{A}}$ & $\ldots$ & $1390^{\mathrm{A}}$ \\
Continuous grazing & $1170^{\mathrm{A}}$ & $220^{\mathrm{A}}$ & $1400^{\mathrm{A}}$ \\
Rotation grazing $^{3}$ & $630^{\mathrm{B}}$ & $770^{\mathrm{B}}$ & $1510^{\mathrm{A}}$ \\
\hline \hline
\end{tabular}

Sector within frontal grazing

\begin{tabular}{llrl}
\hline 1 & $960^{\mathrm{A}}$ & $70^{\mathrm{A}}$ & $1030^{\mathrm{A}}$ \\
2 & $1300^{\mathrm{BC}}$ & $310^{\mathrm{B}}$ & $1610^{\mathrm{B}}$ \\
3 & $1390^{\mathrm{C}}$ & $470^{\mathrm{B}}$ & $1860^{\mathrm{C}}$ \\
4 & $1020^{\mathrm{AB}}$ & $40^{\mathrm{A}}$ & $1060^{\mathrm{A}}$ \\
\hline
\end{tabular}

'Treatment or frontal grazing sector means within herbage component with ulike letters differ $(P<0.10)$

${ }^{2}$ Mean of the 4 frontal grazing sectors. Each sector included $25 \%$ of the area in the pasture with sector 1 being grazing first and sector 4 grazed last.

${ }^{3}$ Mean of the 2 rotation paddocks

This, and an equal total grazing period length were within our initial objectives. These objectives were attained by removing an average of $40 \%$ of the steers in continuous and rotation grazing in mid-July. The management practice of having heavier early season stocking on 'Plains' bluestem appeared effective for efficiently utilizing the very rapid June growth of this species and reducing patch grazing. Visual observations indicated that the rotation system further reduced patch grazing compared to continuous grazing and the 2 to 3 week rotation sequence was effective in maintaining the pastures in a state where the 'Plains' bluestem maturity was somewhat delayed. Forbes and Coleman (1986) reported patterns of spot grazing to be partially broken with heavy grazing pressure early in the season. Subsequently, the percentage of green leaf in the pasture was increased over the grazing season.

Frontal grazing had about 100 more steer-days ha ${ }^{-1}$ grazing than continuous or rotation and $25 \%$ of frontal grazing pastures were cut for hay $\left(3,000 \mathrm{~kg} \mathrm{ha}^{-1}\right.$ yield). However, the fact that end-ofseason standing crop was similar among treatments indicates that the pattern and timing of grazing under frontal grazing must have positively influenced growth and production of 'Plains' bluestem. Although it wasn't measured, depressed forage intake under frontal grazing could have also contributed to the increase in steerdays $\mathrm{ha}^{-1}$. Taliaferro et al. (1984) found that dry matter yield of 'Plains' bluestem was nearly doubled by clipping at 7-week intervals compared to 3-week intervals. Burton et al. (1963) obtained a similar response for 'Coastal' bermudagrass (Cynodon dactylon

Table 1. Daily gains during early, mid, and late summer periods, season-long, and gain and grazing days per hectare averaged over 1991 and 1992 .

\begin{tabular}{|c|c|c|c|c|c|c|}
\hline \multirow[b]{2}{*}{ Treatment } & \multicolumn{4}{|c|}{ Daily gain } & \multirow[b]{2}{*}{ Gain } & \multirow[b]{2}{*}{ Grazing days $^{2}$} \\
\hline & Early & Mid & Late & Season-long & & \\
\hline $\begin{array}{l}\text { Frontal grazing } \\
\text { Continuous grazing } \\
\text { Rotation grazing }\end{array}$ & $\begin{array}{l}0.57^{\mathrm{A}} \\
0.78^{\mathrm{B}} \\
0.84^{\mathrm{B}}\end{array}$ & $\begin{array}{l}0.34^{\mathrm{A}} \\
0.55^{\mathrm{A}} \\
0.57^{\mathrm{A}}\end{array}$ & $\begin{array}{l}0.71^{\mathrm{A}} \\
0.36^{\mathrm{B}} \\
0.66^{\mathrm{A}}\end{array}$ & $\begin{array}{l}0.54^{\mathrm{A}} \\
0.59^{\mathrm{AB}} \\
0.71^{\mathrm{B}}\end{array}$ & $\begin{array}{c}\left(\mathrm{kg} \mathrm{ha}^{-1}\right) \\
281^{\mathrm{A}} \\
286^{\mathrm{A}} \\
321^{\mathrm{A}}\end{array}$ & $\begin{array}{c}\left(\mathrm{SD} \mathrm{ha}^{-1}\right) \\
540 \\
436 \\
448\end{array}$ \\
\hline
\end{tabular}

Column means with unlike letters differ $(P<0.05)$.

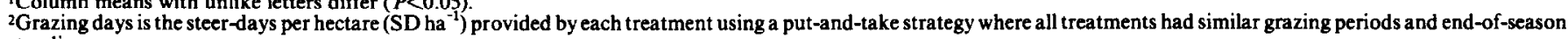
standing crop. 
(L.) Pers.).

Grazing system treatments had an effect on the proportion of grass and forb components in the end-of-season standing crop $(P<0.05$, Table 2). There were fewer forbs under frontal compared to continuous and rotation grazing, suggesting that the opportunity for selection was reduced under frontal grazing. Western ragweed (Ambrosia psilostachya DC.) was the dominant forb species in our pastures and was generally avoided by cattle under continuous grazing. Sectors 1 and 4 had the least forbs within frontal grazing (Table 2). Sector 1 (grazed first) had the highest level of before/after utilization and a fair portion of this sector was grazed during the initial training period. Steers had virtually no opportunity for selection during the training period because they were not proficient at advancing the frontal fence and grazed all species to try to meet their intake needs. Sector 4 was cut for hay in mid-June and a large portion of the forb biomass was removed at that time. Conversely, sectors 2 and 3 generally had larger amounts of grass in the end-of-season standing crop compared to sectors 1 and 4. The 'Plains' bluestem was increasing in maturity and decreasing in palatability by the time these sectors were being frontally grazed.

\section{Management Implications}

The mechanical design and components of our frontal grazing system were quite adequate in terms of the system's operation and interaction with the livestock herd. Frontal grazing requires intensive management and is probably not practical on native rangelands. The system was developed on legume and cool-season grass pastures where rapid consumption of the forage followed by a rest period may favor an increase in forage yield, and consequently, an increase in production per unit area. However, in our trials, frontal grazing did not result in an increase in gain per hectare compared to conventional grazing systems although frontal grazing did provide an increase in grazing days per hectare. Increased grazing days, at least in part, may be attributable to the unique timing and pattern of defoliation under frontal grazing, which produces a positive response on forage production. Highly productive forages with long growing seasons, along with a legume to increase quantity and quality of the forage, might result in frontal grazing increasing productivity per unit of land.

\section{Literature Cited}

Achaval O'Farrell, F. de. 1991. A comparison of frontal and continuous systems of grazing. M.S. Thesis. Texas A\&M Univ., College Station.

Brundage, A.L., and W.E. Petersen. 1952. A comparison between daily rotational and continuous grazing. J. Dairy Sci. 30:623-630.

Burton, G.W., J.E. Jackson, and R.H. Hart. 1963. Effects of cutting frequency and nitrogen on yield, in vitro digestibility, and protein, fiber, and carotene content of Coastal bermudagrass. Agron. J. 55:500-502.

Conway, A.G. 1963. Effect of grazing management on beef production. II. Comparison of three stocking rates under two systems of grazing. Irish J. Agr. Res. 2:243-258.

Dabo, S.M., C.M. Taliaferro, S.W. Coleman, F.P. Horn, and P.L. Claypool. 1988. Chemical composition of Old World bluestem grasses as affected by cultivar and maturity. J. Range Manage. 41:40-48.

Forbes, T.D.A., and S.W. Coleman. 1986. Herbage intake and ingestive behavior of grazing cattle as influenced by variation in sward characteristics, p. 141-152. In: F.P. Horn et al. (eds.), Grazing-lands research at the plant-animal interface, Winrock Int., Morrilton, Ark.

Hart, R.H. 1980. Determining a proper stocking rate for a grazing system. p. 49-64. In: K.C. McDaniels and C. Allison (eds.) Grazing Management Systems for Southwest Rangelands Symp. New Mexico State Univ., Las Cruces.

McMeekan, C.P. 1947. New Zealand pasture: its value for milk and meat production. Australian Vet. J. 23:105-113.

Morley, F.W.H. 1968. Pasture and grazing management, p. 81-102. In: B. Wilson (ed.), Pasture improvement in Australia, Sydney, Australia.

Mott, G.0. 1960. Grazing pressure and the measurement of pasture production, p. 606-611. In: C.L. Skidmore (ed.), Proc. VIII Int. Grassl. Congr. Univ. Reading, Oxford, England.

SAS Institute, Inc. 1988. SAS/STAT User's Guide, release 6.03 edition, SAS Institute Inc., Cary, N.C.

Taliaferro, C.M., F.P. Horn, R.M. Ahring, and D.L. Weeks. 1984. Yield and quality of caucasian and plains bluestem grasses as affected by clipping interval. Agron. J. 76:769-772.

Vickery, P.J., I.L. Bennett, and G.R. Nicol. 1980. An improved electronic capacitance meter for estimating herbage mass. Grass and Forage Sci. 35:247-252.

Volesky, J.D. 1990. Frontal grazing: Forage harvesting of the future? Rangelands 12:177-181.

Volesky, J.D., D.P. Mowrey, and F. Achaval. 1990. Frontal grazing: A new method of forage harvesting, p. 142-146. In: Proc. Amer. Forage and Grassl. Conf., Blacksburg, Va.

Watkin, B.R., and R.J. Clements. 1978. The effect of grazing animals on pastures, p. 273-290. In: J.R. Wilson (ed.) Plant relationships in pastures, CSIRO, Melbourne, Australia. 